\title{
Retail Bank Interest Rate Pass-through: Is Chile Atypical?
}

\author{
Marco A. Espinosa-Vega \\ International Monetary Fund \\ Alessandro Rebucci \\ International Monetary F und
}

There is little disagreement among economists that monetary policy affects the rate of inflation and, at least in the short run, the level of real economic activity. From an operational perspective, many central banks currently target a short-term market interest rate. This is done on the premise that this instrument is linked more or less stably to the final objectives of monetary policy through the socalled transmission mechanism of monetary policy.

Most of the literature on the transmission mechanism of monetary policy implicitly assumes that once the monetary authority's target rate is changed, short-term market and retail banking rates will follow suit-that is, there will be immediate and complete "passthrough" to retail banking rates (see, for example, Bernanke and Gertler, 1995; Bernanke and Gilchrist, 1999). If the pass-through to banking interest rates were sluggish or incomplete, those specific channels of the transmission mechanism of monetary policy that operate through banking rates would also be affected.

Stickiness of retail banking interest rates was first documented in the U nited States by Hannan and Berger (1991) and Neumark and Sharpe (1992). These authors study deposit rate setting using econometric models that are based on theoretical models developed to

We are grateful to Pablo García, J . Rodrigo Fuentes, Alain Ize, Saul Lizondo, Steve Phillips, Solange Bernstein, Verónica Mies, Klaus Schmidt-Hebbel, and Luis Oscar Herrera for useful discussions and comments. Andy Swiston provided outstanding research assistance. The views expressed in this paper are those of the authors and do not necessarily represent the views or policy of the International Monetary Fund or of the Central Bank of Chile.

Banking Market Structure and Monetary Policy, edited by Luis Antonio Ahumada and J. Rodrigo Fuentes, Santiago, Chile. (c) 2004 Central Bank of Chile. 
analyze price stickiness in goods markets. Implicit in their analyses is the notion that banks cannot influence the behavior of lending rates because they are atomistic players in that market. Hence, the authors assume that the pass-through to retail lending rates is immediate and complete. They then investigate the degree to which market power in the deposit market affects stickiness in deposit interest rates by looking at disaggregated data from large surveys of banks. Among other things, these early studies find that the passthrough to deposit rates is asymmetric, with lower pass-through when the market rate is increasing than when it is decreasing. These authors inter pret their findings of asymmetric pass-through as evidence of market power in the deposit market.

Cottarelli and Kourelis (1994) were the first to measure and compare the degree of pass-through to lending rates across countries, with both devel oped and devel oping countries included in their sample. Their empirical analysis is based on an autoregressive distributed lag specification estimated with aggregate time series. They estimate the response of lending rates to changes in money market rates at different time horizons. They then regress these responses across countries against various measures of financial market structure, while also controlling for other country characteristics such as the effects of interest rate volatility. The analysis thus not only documents the extent to which interest rate pass-through differs across countries, but al so tries to explain why this is the case. In particular, the authors suggest that the following three factors might reducethe degree of stickiness: the existence of a market for negotiable shortterm instruments; relatively limited volatility of money market rates; and relatively weak barriers to entry (though they do not find evidence that market concentration per se affects loan rate stickiness). Based on these findings, they suggest that policymakers can enhance the effectiveness of monetary policy by enriching the menu of shortterm marketable instruments and removing barriers to competition, rather than trying to reduce the level of market concentration.

More recent studies of the interest rate pass-through use similar econometric specifications, but they focus mostly on euro-area countries. Mojon (2000), for example, measures the degree of pass-through for lending and deposit rates in five European countries: Belgium, France, Germany, the Netherlands, and Spain. Heassumes that there is full pass-through in the long run and concentrates on estimating its size in the short term. He then goes on to study different interest rate cycles, trying to uncover possible asymmetries in the pass-through 
across states of this cycle. His main findings are that retail rates respond sluggishly to changes in the money market rate, that shortterm rates generally respond faster than long-term rates, and that there is asymmetry in the degree of pass-through, with a larger passthrough tolending rates when the money market rate increases than when it decreases and the opposite effect for deposit rates. He also finds that the results vary somewhat across countries. He conjectures that this heterogeneity could be due to differences in the microeconomic structure of the different countries' banking systems, but he provides no direct evidence on this.

A second example is provided by Bondt (2002), who estimates an aggregateautoregressive distributed lag specification reparameterized as an error-correction model for the euro area as a whole. In his analysis, deposit and lending rates of different maturities are paired with government bond yiel ds of similar maturities. Hefinds that passthrough is incomplete on impact for both lending and deposit rates, reaching only 50 percent within a month, but that it is complete in the long run for most lending rates. ${ }^{1}$

Following Cottarelli and Kourelis (1994), Mojon (2000), ${ }^{2}$ and Bondt (2002), this paper compares Chile with a number of other countries. Specifically, it provides a set of stylized facts about the pass-through in Chile and compares them against the benchmark of pass-through in a group of advanced economies. We estimate the aggregate, dynamic reduced-form relation between the money market interest rate and retail bank rates for Australia, Canada, Chile, New Zealand, the United States, and a number of European countries, based on monthly data from 1993 to 2002, and we try to interpret the evidence in light of previous studies and analyses. ${ }^{3}$ We do not, however, test explicit hypotheses on the structure of the Chilean banking system. Theanalysis is based on an autoregressive distributed lag specification reparameterized as an error-correction model, which is a standard methodology used in this literature. We estimate both the size and the speed of the pass-through from policy to retail banking rates, in the short run (on impact, within a month) and in the long run (in the steady state).

1. The pass-through from policy interest rates to retail banking rates may still be incomplete if the pass-through from policy rates to government bond yields is incomplete.

2. See also Borio and Fritz (1995).

3. See Berstein and Fuentes (in this volume) for a complementary analysis using Chilean bank-by-bank data. 
For Chile, we also ask whether these estimates differ across states of the interest rate or the monetary policy cycle and whether they have changed over time, especially after the 1998 Asian crisis and after the introduction of "nominalization" of the policy interest rate target in 2001. By implementing these robustness checks, we provide indirect evidence on whether the interest rate pass-through has been affected by market power in the banking sector-consistent with the findings of Hannan and Berger (1991) and Neumark and Sharpe (1992) for the United States and Mojon (2000) for Europe-or by other factors such as interest rate volatility-consistent with Cottarelli and Kourelis (1994) for devel oping countries.

Our main conclusion is that theinterest rate pass-through in Chile, overall, is not significantly different from that of the other economies considered. In particular, we find that the size of Chile's Iong-run passthrough is slightly smaller than that of Australia, Canada, and theUnited States and is comparable to that of New Zealand and the European countries in our sample. In Chile, however, thespeed of the pass-through is faster than in Australia, New Zealand, and several of the European countries. Moreover, it is only slightly slower than the pass-through in the prime rate for Canada and the United States in the short term.

Wealso find that both the size and the speed of the pass-through declineas the maturity of the bank instruments considered increases, not only for Chile but also for most of the countries in the sample. Unlike the studies reviewed above, we do not find evidence for Chile of significant asymmetry in the pass-through. We do find some evidence of parameter instability over time, especially around the 1997-98 Asian and Russian crises, but we do not find marked evidencethat there has been any further significant difference following the nominalization of Chile's interest rate targets.

A distinctive institutional feature of Chile is that there are two different types of domestic currency deposits and Ioan instruments: standard nominal instruments and instruments denomi nated in the Unidad de Fomento (UF), a unit of account that indexes financial contracts and transactions to the previous month's inflation rate. We look at both nominal and UF interest rates, but find that the results are broadly comparable, especially in the long run: the size of the long-run pass-through is about the same across these instruments. In the short run, however, the pass-through for most UF rates appears slightly smaller than the pass-through for nominal rates.

As we explain below, weinterpret the aggregate evidence reported on the symmetry and instability of the pass-through in Chile as 
suggesting that the behavior of retail banking interest rates is likely to be affected by factors other than market power in the banking system, most notably external shocks. Chile is a very open economy both on the current and the capital accounts of the balance of payments. The Chilean banking system is thus exposed to competition and entry from foreign banks (even if its current structure appears rather concentrated), and this might be mitigating the market power of individual banks. At the same time, Chile's openness, together with the fact that the country was buffeted by significant external shocks during our sample period, might have affected banks' reactions to policy changes. High external volatility may also force frequent policy changes.

On balance, Chile's interest rate pass-through at the aggregate level does not appear too different from that of the other countries considered. These results, however, would not be inconsistent with the presence of some differences in the pass-through across individual bank instruments. A natural extension of our work would therefore be to investigate explicit structural hypotheses across countries based on microeconomic data and the predictions of an open economy model of banking system competition.

The remainder of the paper proceeds as follows. Section 1 describes the data we use and presents a brief review of key crosscountry similarities and differences in the raw data. Section 2 outlines the empirical model used. Section 3 reports the estimation results, and section 4 concludes.

\section{The Data and a Few Stylized Facts}

This section describes the dataset we constructed, presents relevant summary statistics, and highlights the main features of the data and its key moments.

\subsection{Sources and Definitions}

In addition to Chile, we consider Australia, Belgium, Canada, France, Germany, the Netherlands, New Zealand, Spain, and the United States. In all cases except Chile, the sample period is April 1993 to J une 2002; for Chile, the sample ends in September 2002. The data arefrom national central banks, theE uropean Central Bank, and the I nternational Monetary Fund. A complete list of the interest 
rate series used is presented in the appendix. These series are also featured in figures 1 through 7.

The money market rate is an overnight interbank lending rate. The only exception is Australia, for which we use the thirteen-week treasury bill rate owing to apparent anomalies in the data for the interbank lending rate.

Retail interest rates are classified into three maturity buckets. Retail interest rates on instruments with maturities of less than three months are classified as short-term rates, rates on instruments with maturities of three months to a year are classified as medium-term rates, and rates on instruments with maturities of one to three years are classified as long-term rates.

The lending rates are for commercial loans, with three exceptions: Canada's medium- and long-term lending rates are for mortgages; the German I ong-term lending rate is for consumer loans; and the Chilean rates are for both consumer loans and commercial loans. For the United States, the only lending rate we consider is the prime rate, which is the base on which many other loan rates are calculated. Canada's short-term lending rate is defined similarly, while its long-term lending rate is for one-year and three-year conventional mortgages. ${ }^{4}$ The lending rates for Germany and Spain are averages for transactions that took place throughout the month, while for Belgium, France, and the Netherlands they are end-of-period rates. For Australia and New Zealand, we do not have data on lending rates by maturity. For New Zealand, therefore, we used the weighted average base business rate charged by the six largest banks (each bank reports the average rate on new loans of all maturities weighted by amount); for Australia, we used the weighted average rate charged by banks on business loans.

Our deposit rate series are generally more homogeneous. Most of them are for demand deposits, certificates of deposit, or time deposits, with maturities in the three buckets described above. ${ }^{5}$

4. Using the prime lending rate for Canada and, in particular, the United States might bias the cross-country comparison against all other countries. In fact, these are among the very few interest rate series displaying full pass-through in the long run. The prime rate is a lending rate applied to the best borrowers. It usually moves immediately following policy announcements to signal banks' readiness to move their pricing schedule, but it does not necessarily move one-to-one with the policy rate. Therefore, it is not evident that pass-through should be complete in the long run for prime rates.

5. We do not use short-term deposit rates for Belgium, France, and the Netherlands, although they are available, because they do not appear to be market determined. 


\section{Figure 1. Short-term Deposit Rates and Money Market}

Rates, 1993 to 2002 (percent)
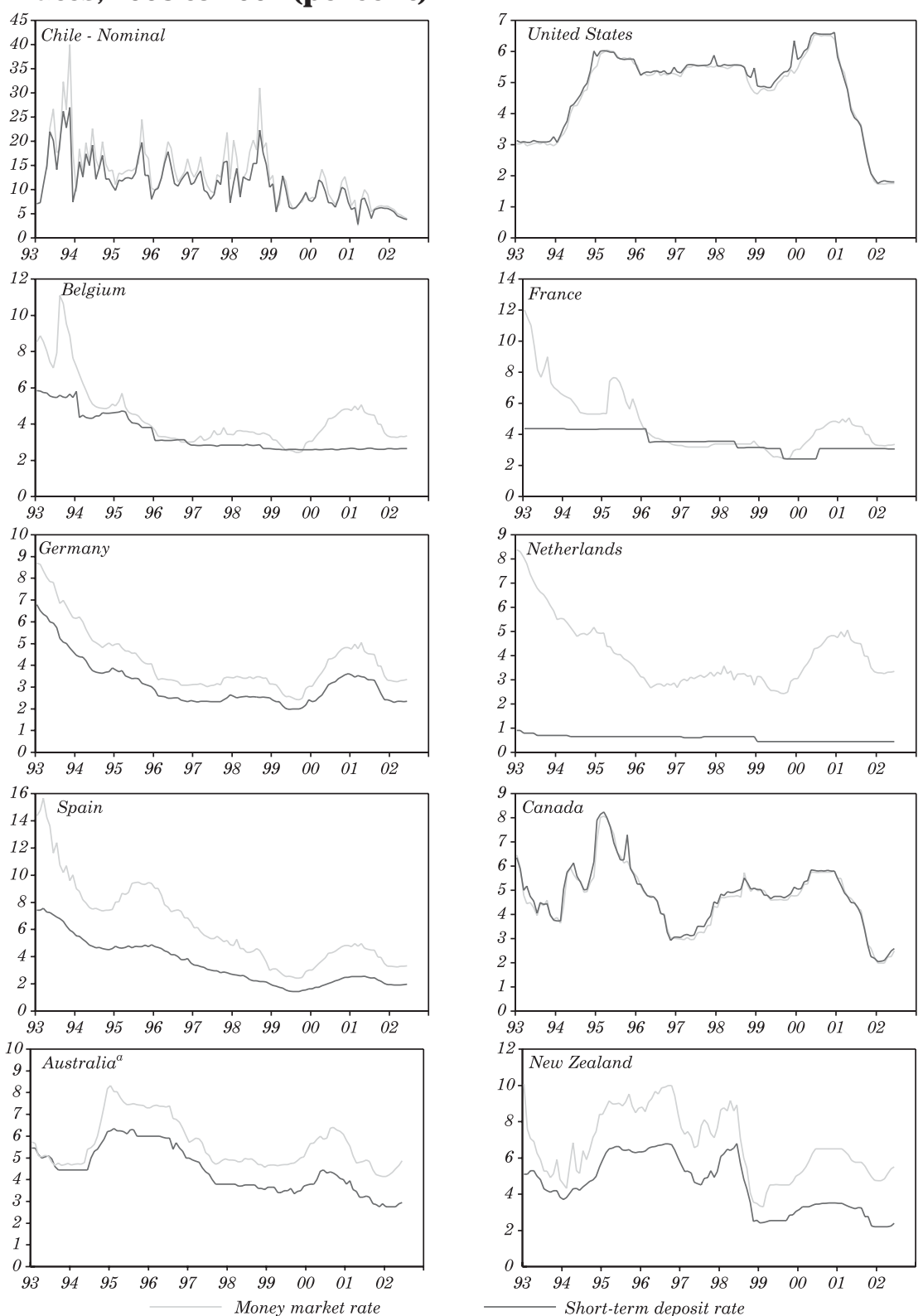

Source: National central banks, the European Central Bank, and the International Monetary Fund. a. Money market rate is replaced by thirteen-week treasury bill. 
Figure 2. Medium-term Deposit Rates and Money Market Rates, 1993 to 2002 (percent)
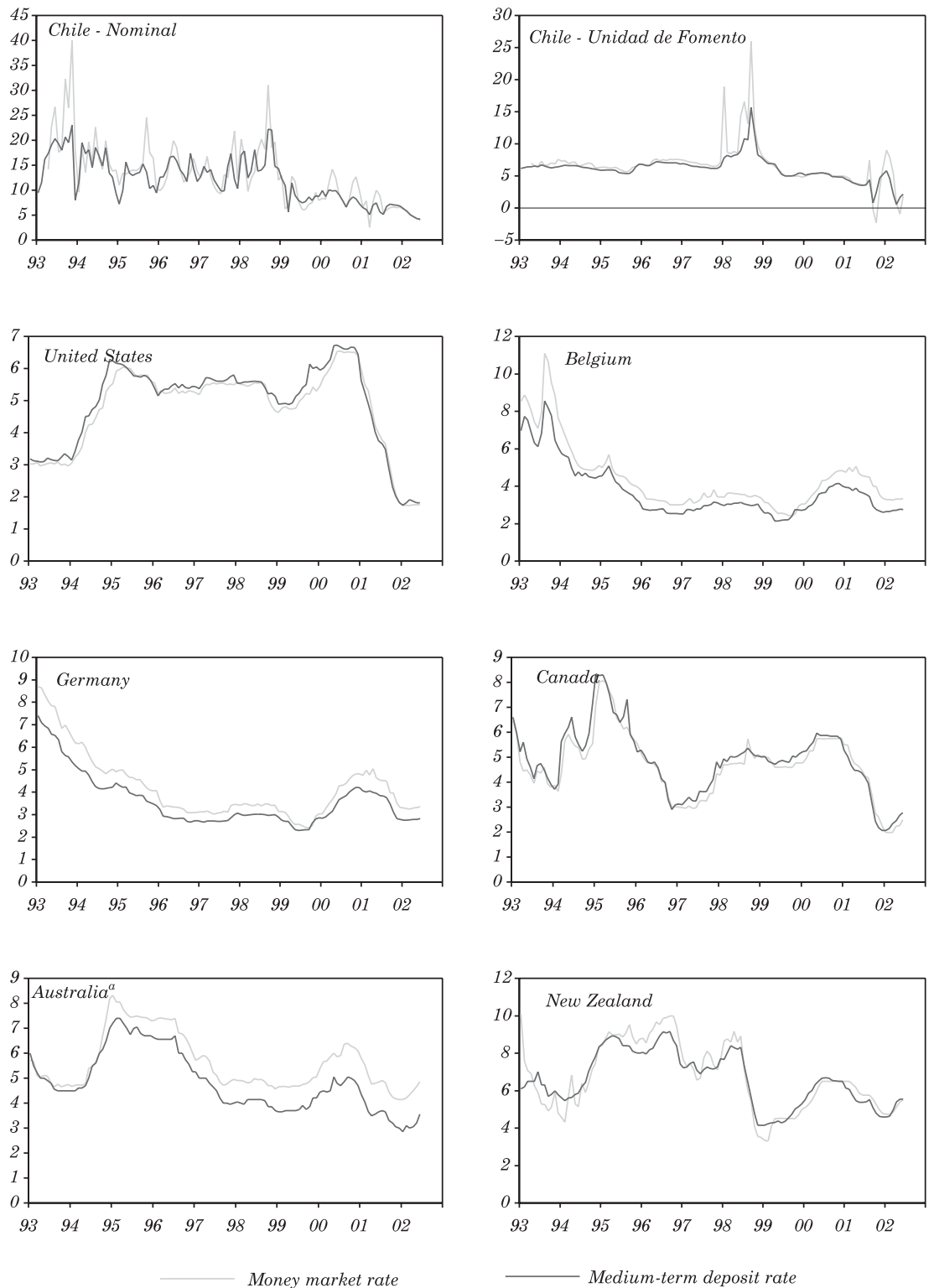

Source: National central banks, the European Central Bank, and the International Monetary Fund. a. Money market rate is replaced by thirteen-week treasury bill. 
Figure 3. Long-term Deposit Rates and Money Market Rates, 1993 to 2002 (percent)
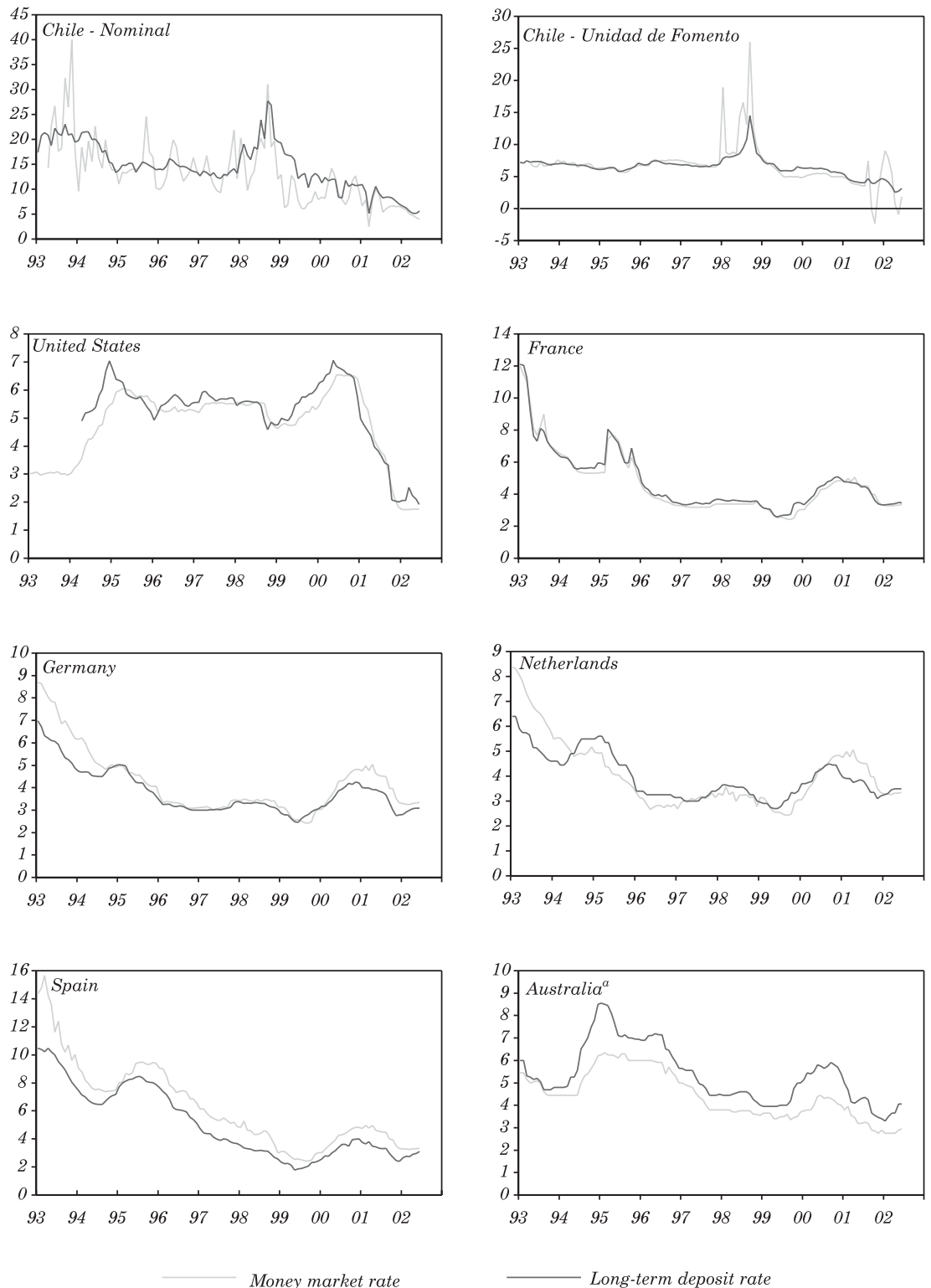

Source: National central banks, the European Central Bank, and the International Monetary Fund. a. Money market rate is replaced by thirteen-week treasury bill. 
Figure 4. Weighted Average Lending Rates and Money Market Rates, 1993 to 2002 (percent)
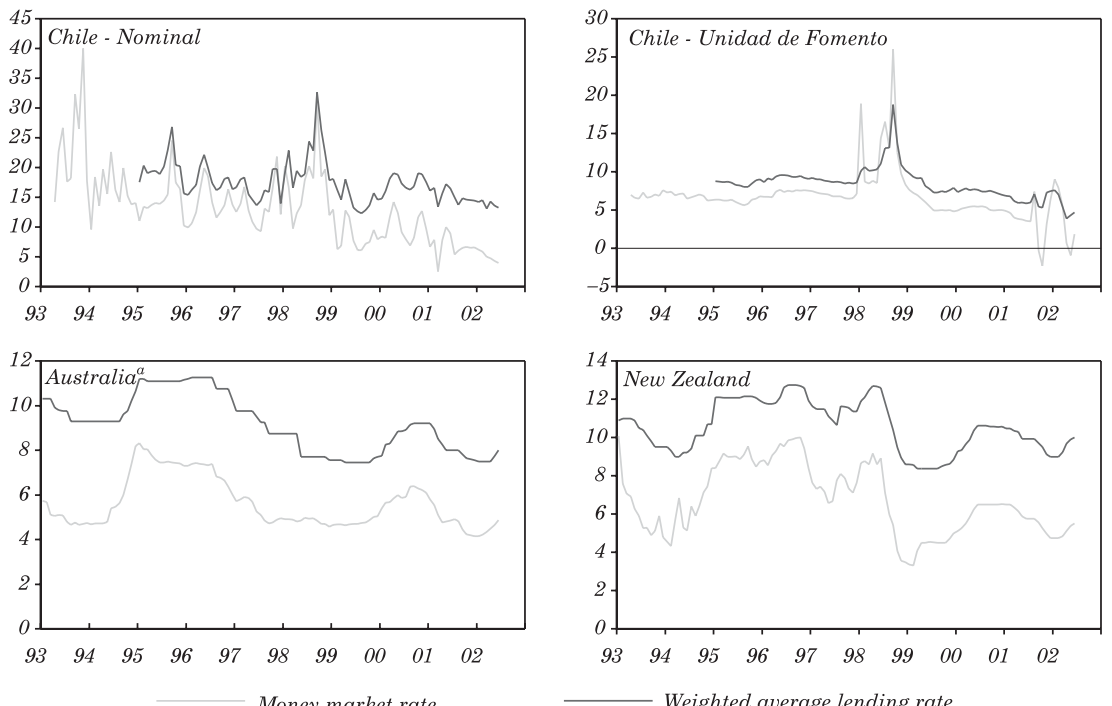

Money market rate

Weighted average lending rate

Source: National central banks, the European Central Bank, and the International Monetary Fund. a. Money market rate is replaced by 13-week treasury bill.

\section{Figure 5. Short-term Lending Rates and Money Market}

\section{Rates, 1993 to 2002 (percent)}
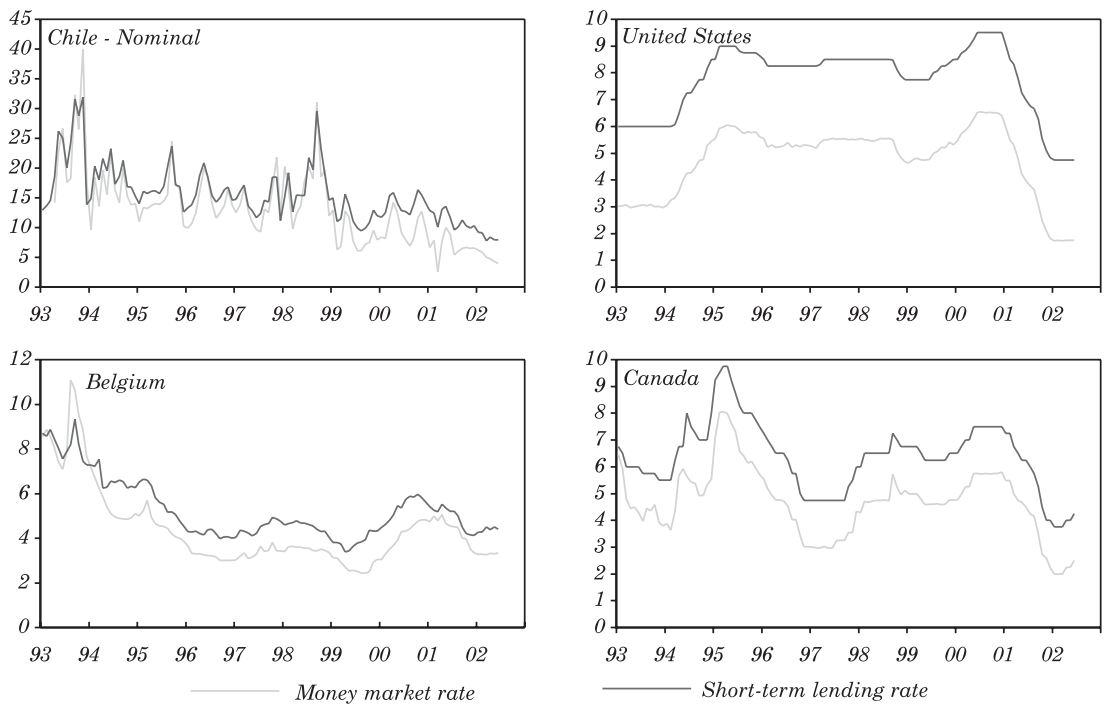

Source: National central banks, the European Central Bank, and the International Monetary Fund. 
Figure 6. Medium-term Lending Rates and Money Market Rates, 1993 to 2002 (percent)
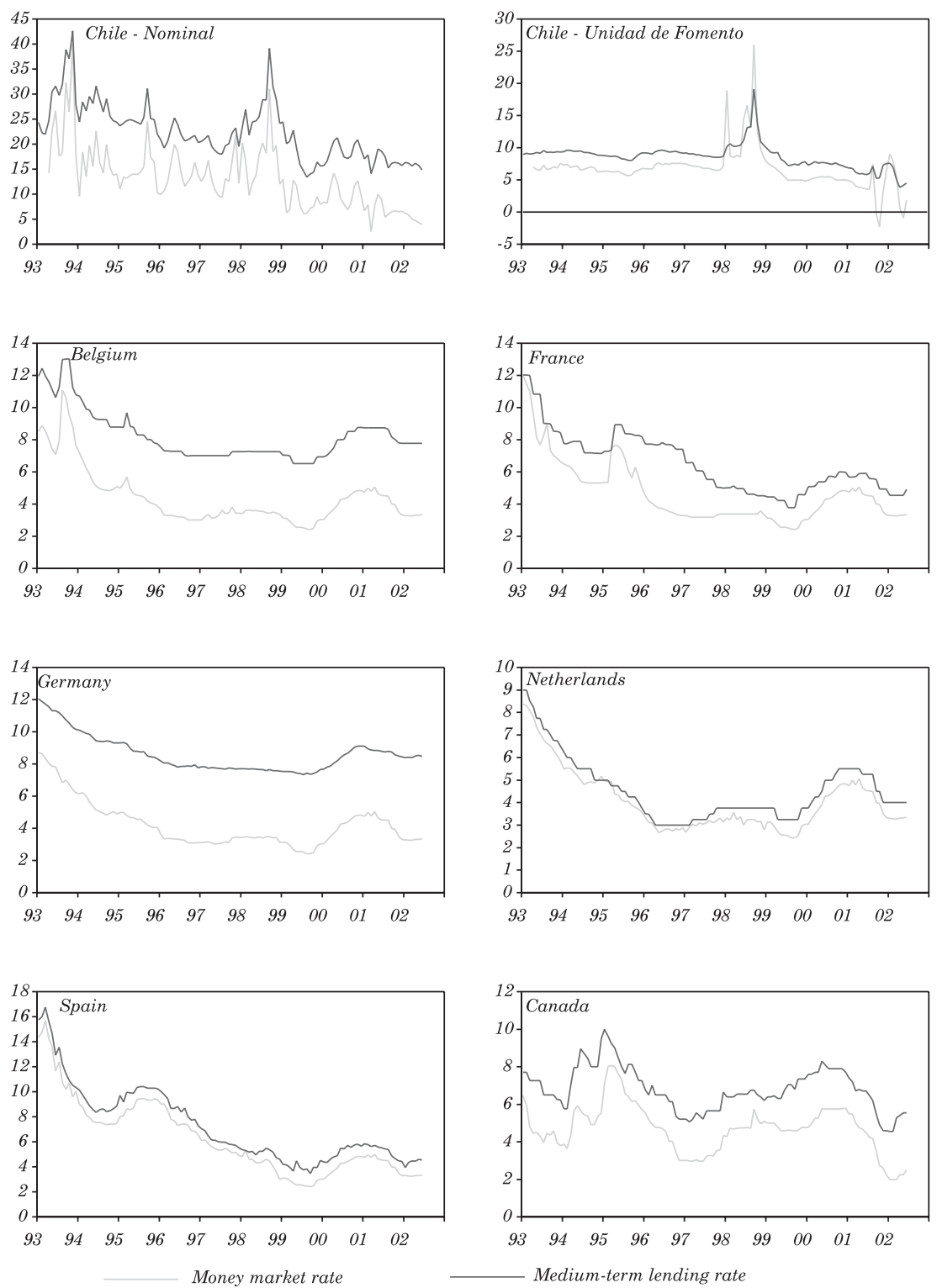

Source: National central banks, the European Central Bank, and the International Monetary Fund. 
Figure 7. Long-term Lending Rates and Money Market Rates, 1993 to 2002 (percent)
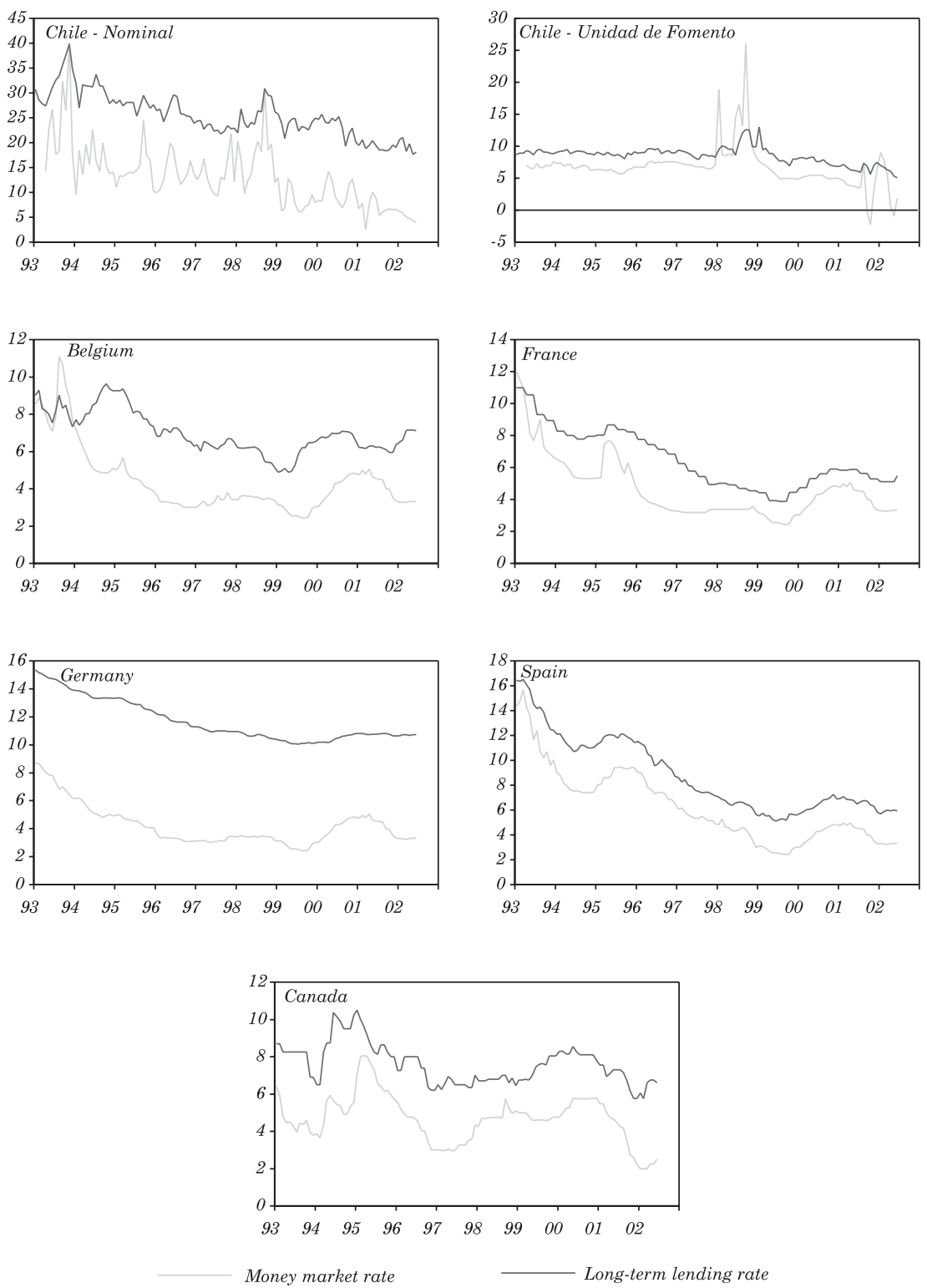

Source: National central banks, the European Central Bank, and the International Monetary Fund. 
For Chile, we consider both nominal domestic currency and UF interest rates. Studying UF interest rates is important because most bank intermediation was based on this unit of account before August 2001. At that time, the Chilean Central Bank stopped targeting the UF-denominated money market rate and switched to more conventional nominal interest ratetargeting - a change we call nominalization in the rest of the paper.

\subsection{Summary Statistics for the Raw Data}

Preliminary analysis of the data reveals some noteworthy similarities and differences between Chile and the other countries considered. Over the sample period, Chilean interest rates are on average higher, more vol atile, and less persistent than the interest rates for the other countries. In Chile, however, the degree of comovement between retail bank interest rates and the money market rate is essentially the same as in other countries. These stylized facts are highlighted in tables 1 through 4, which report summary statistics for the interest series of all countries considered.

Chilean data display the highest sample mean, even in UF terms, whilethe Netherlands shows the lowest average level of interest rates (table 1). This may reflect the generally higher rate of inflation in Chile during most of our sample period, but it could al so reflect other factors, such as higher average risk premia or faster economic growth in Chile. In any case, it is not evident whether or how higher average interest rates per se might affect the pass-through.

Chilean data display the highest interest rate volatility, for both UF and nominal rates, as measured by the sample standard deviation (table2). At all maturities, theinterest rates for Australia, Canada, and the U nited States exhibit the lowest volatility. Higher volatility is usually associated with higher uncertainty, which in turn may slow down agents' reaction to change by exacerbating precautionary behavior and increasing the option value of waiting.

Chile has the lowest interest rate persistence in our sample, again whether we look at UF or nominal rates (table 3). In contrast to all other countries, Chile's interest rate series also appear stationary. 


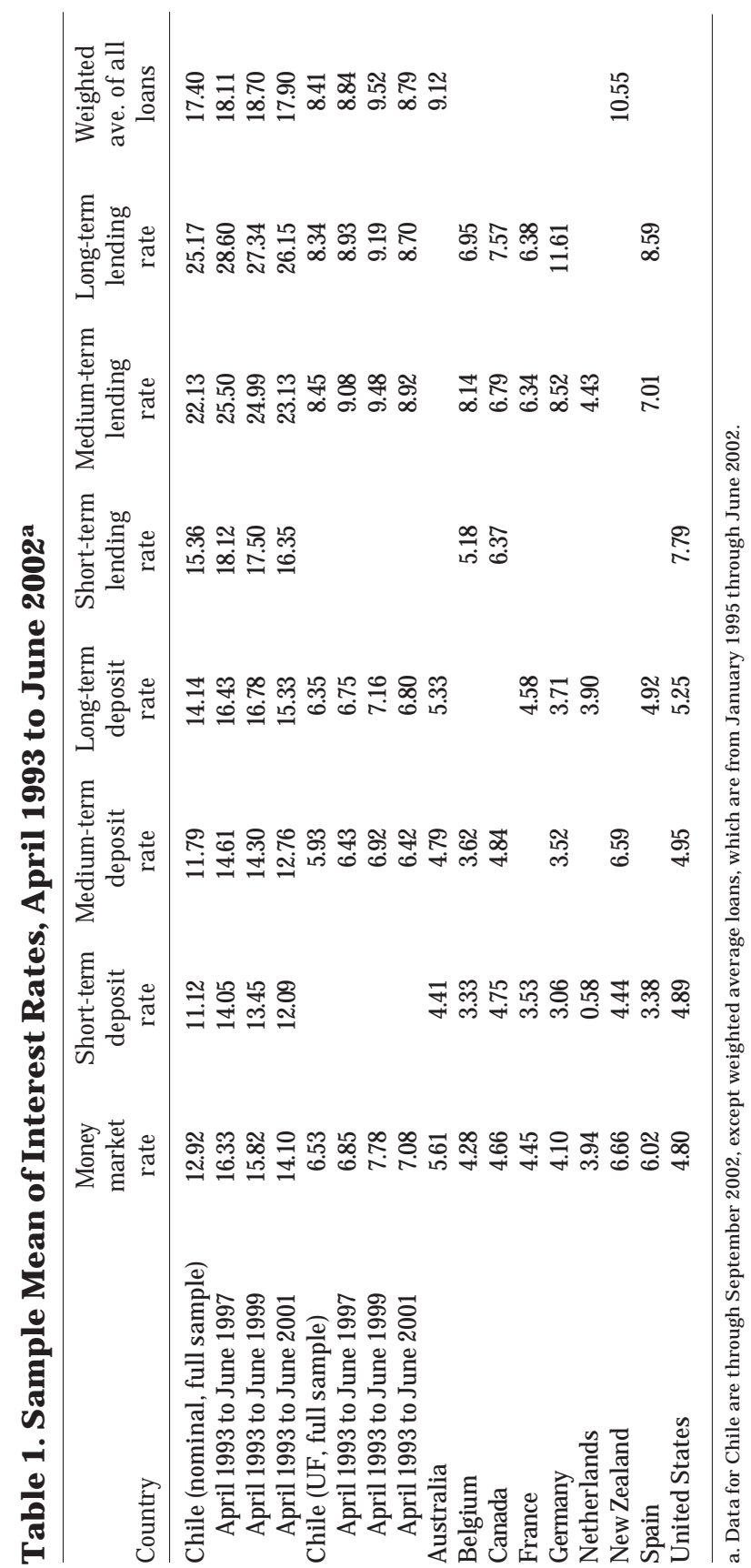




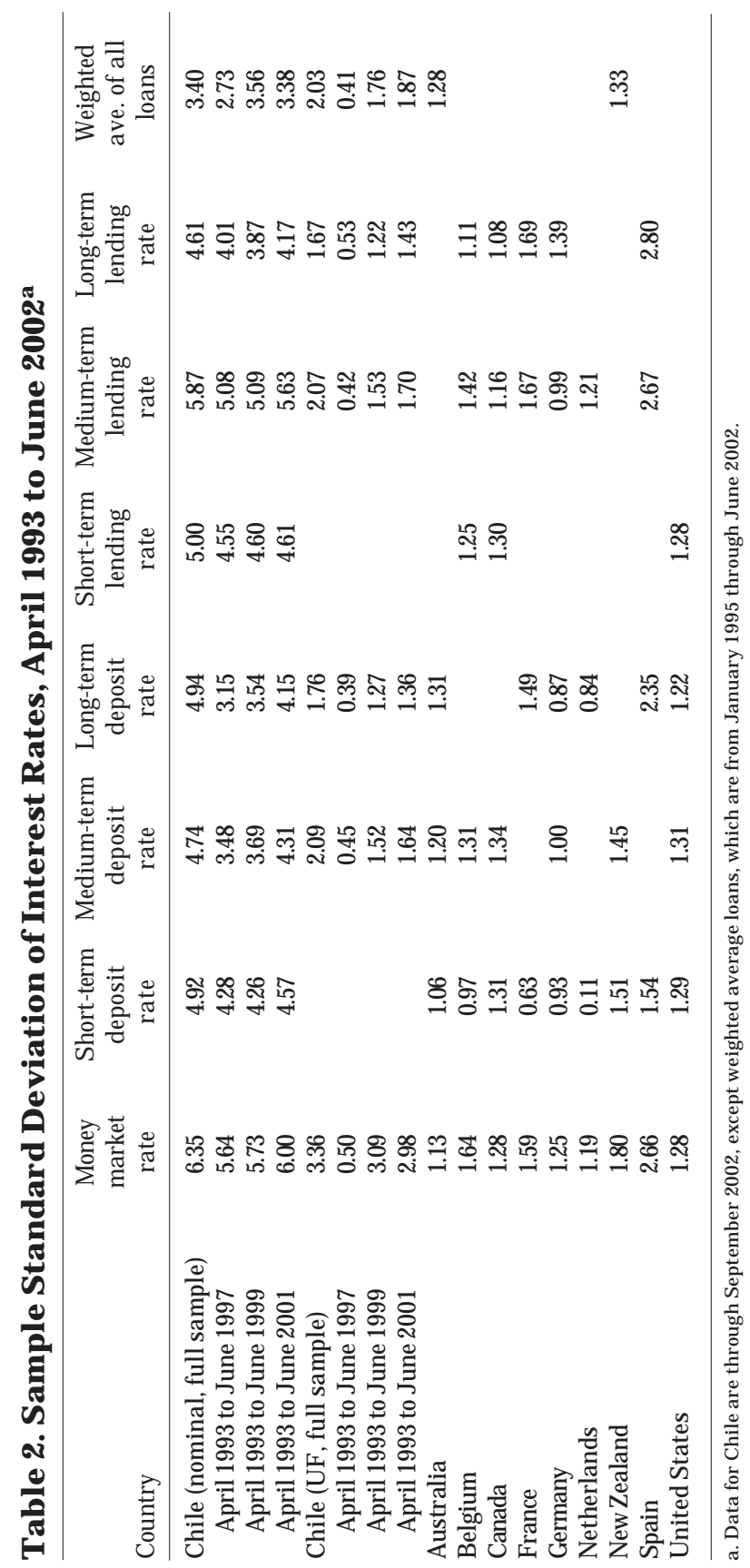




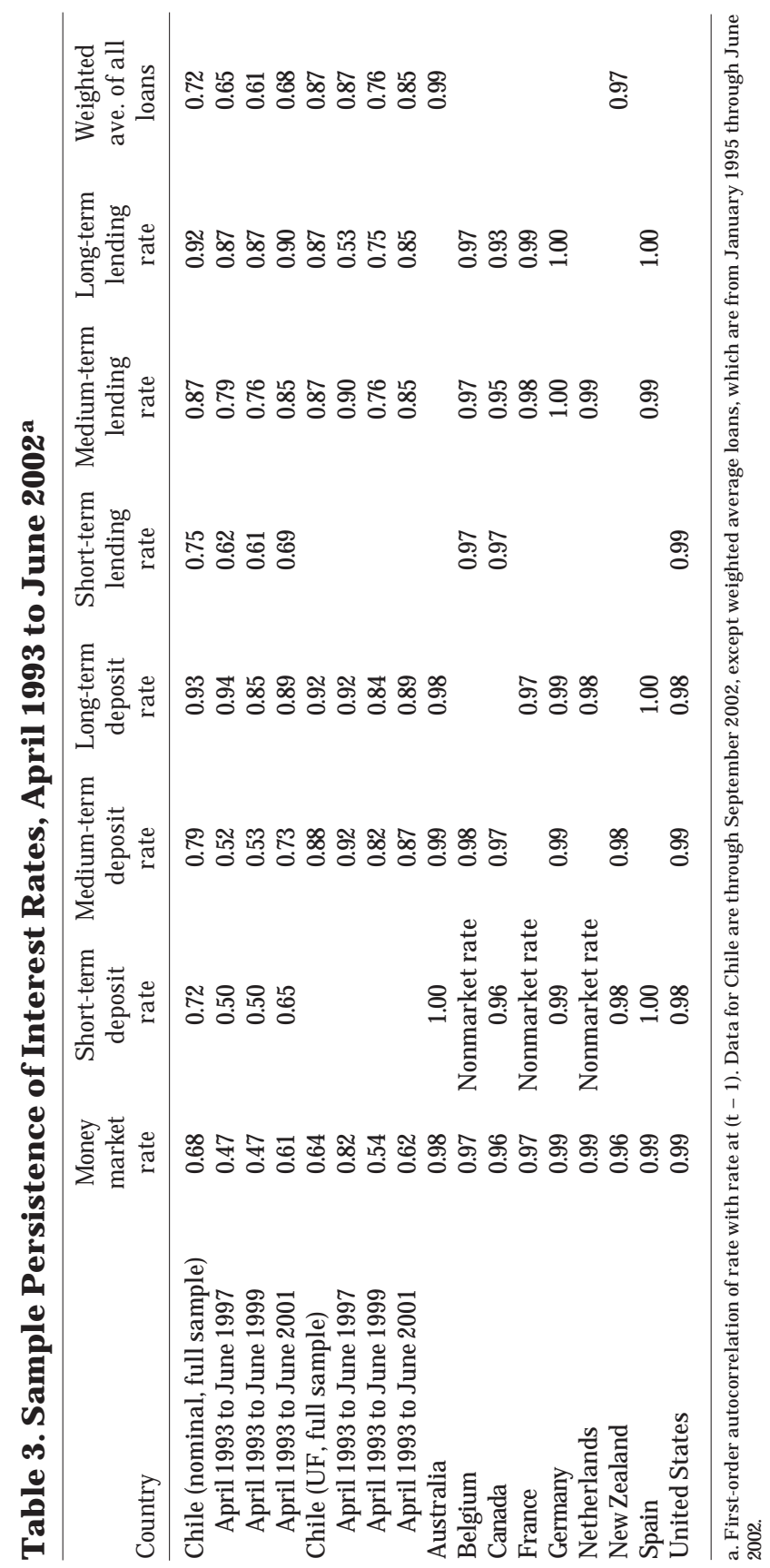


Over the sample period, the null hypothesis that Chilean interest rates have a unit root without drift can be rejected with 99 percent confidence for all rates except the nominal long-term deposit rate. ${ }^{6}$ This hypothesis cannot be rejected for most other countries.

External shocks are more likely than policy to explain higher volatility and lower persistence in Chile relative to other countries. On the one hand, the lower persistence of interest rates in Chile may suggest that there have been periods in which the central bank was not willing to smooth rates to the same extent as some other central banks in the sample. Prior to the recent switch to nominal interest rate targeting, the UF money market rate-the old target ratefollowed a fairly smooth pattern, except during the Asian and Russian financial crises (see figure 2). On the other hand, it is also possible that the Chilean economy has simply been subject to larger and more frequent external shocks than the other economies throughout sample period. For instance, Edwards (1998) emphasizes the role of external factors in explaining interest rate vol atility in emerging economies. In addition, Caballero (2000) argues that the financial reforms adopted in Chile in recent years may have produced speedier transmission of external shocks, which in turn would imply greater measured volatility. Larger and more frequent external shocks than in other countries would naturally require more frequent adjustments of policy interest rates.

In any case, all countries in the sample exhibit a relatively high degree of contemporaneous correlation between retail banking interest rates and the relevant money market rate (table 4 and figures 1 through 7). For Chile, in particular, the first principal component explains more than 90 percent of the variability of the ten interest rate series considered, suggesting that a single common factor explains most of the comovement of these data (results not reported). ${ }^{7}$ The relatively high value of the simple correlation between the money market rate and retail bank rates also suggests that this common factor is most likely associated with domestic monetary policy.

Interestingly, table 4 shows that the strength of this correlation tends to decline with the maturity of the retail rate in most countries.

6. The regression includes a constant, a linear trend, and a variable number of lags between one and five. These results are not reported in the paper, but they are available from the authors on request (as are all other nonreported results).

7. Since we can reject the null hypothesis of a unit root in the Chilean interest rate series, cointegration tests would not be informative on the degree of comovement between the money market interest rate and retail bank rates. 


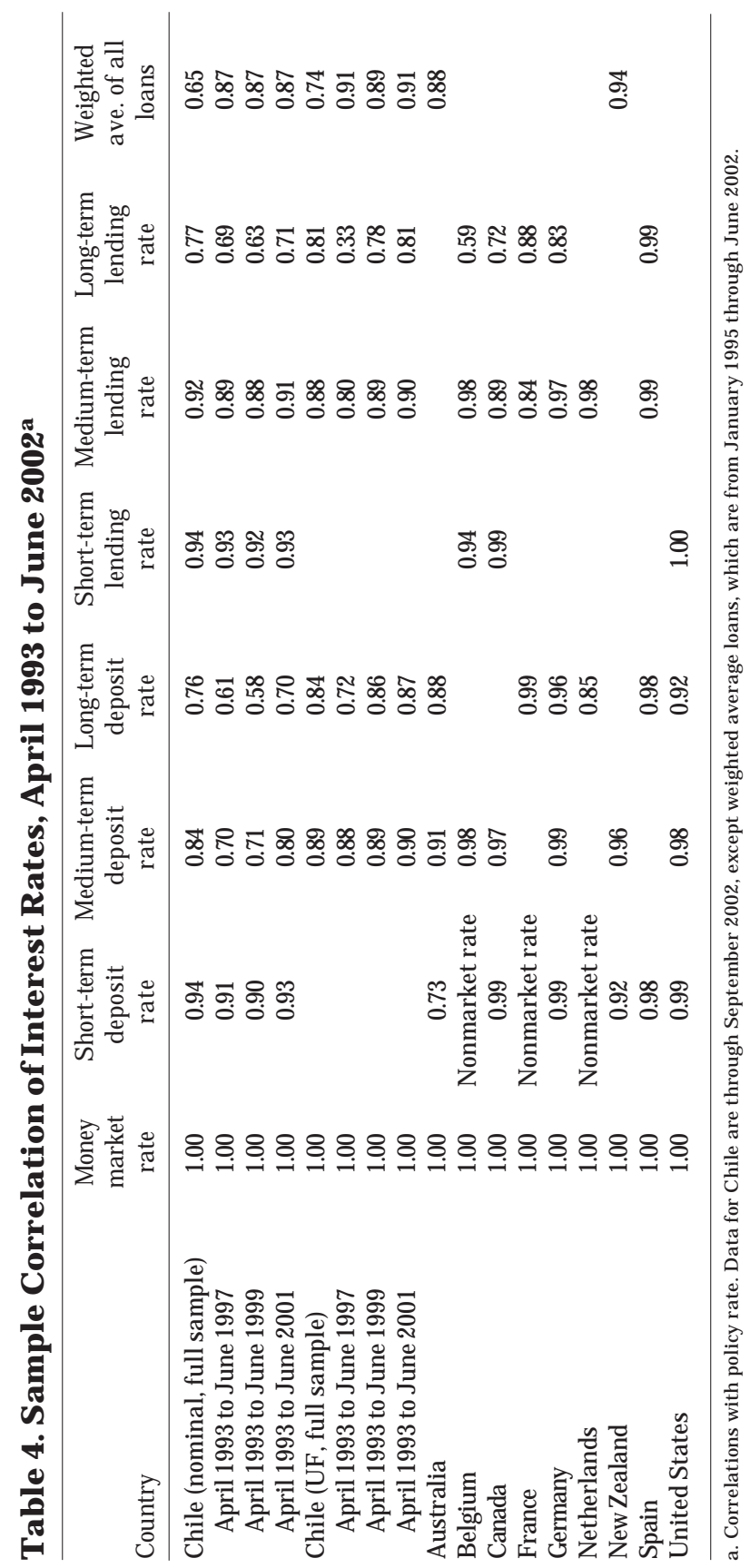


In addition, an analysis of the lagged autocorrelation between the money market interest rate and retail bank rates shows that it is highest within the first month for most of the countries considered. However, changes in money market rates do not seem to pass through completely to retail banking rates, except for Australia, Canada, and the United States. In fact, money market rates appear more volatile than the retail rates.

A first look at the (unconditional) moments of the data thus suggests that there are both important similarities and differences between Chile and the group of other countries considered: Chilean interest rates comove with the policy rate as strongly as those of other countries, with the strength of this comovement decreasing with the maturity of the bank instrument analyzed. In addition, the volatility of the policy rate is slightly higher than the volatility of retail interest rates, as in most other countries. This indicates that policy and retail interest rates generally move very cl osely together, even though not all changes in the former are passed on to thelatter. However, the average level and volatility of Chilean interest rates is higher than in other countries, while persistence is lower.

As we shall see in the next section, if the degree of (conditional) comovement between policy and retail interest rates is comparable across countries, then lower persistence in Chilean rates would most likely be due to higher volatility. It would follow that the key difference between Chile and other countries would be the greater interest rate volatility in Chile. On the other hand, as mentioned earlier, both interest rate volatility and market power in the banking system may affect the pass-through process. In the last section of the paper, therefore, we compare the pass-through across countries and try to investigate the relative role of volatility and market power in this process by using a simple aggregate, dynamic reduced-form econometric model, which we now present.

\section{The E conometric Model}

To analyze the dynamic reduced-form relation between retail banking interest rates and the money market rate, we first specify and estimate the following simple autoregressive distributed lag (ARDL) model:

Rtail $R_{t}=\alpha_{o}+\alpha_{1} t+\alpha_{2} M M R_{t}+\alpha_{3} R_{\text {tail }} R_{t-1}+\alpha_{4} M M R_{t-1} ，$ 
where RTAILR is the rel evant bank interest rate, MMR is the money market rate, and $t$ is a time trend. The trend is intended to capture the disinflation process and other factors that change slowly over time (for example, financial market liberalization and other structural reforms).

For all the countries considered, we specify equation (1) including only one lag of both the retail and the policy interest rate, which is here assumed to be exogenous-a reasonable assumption within the month. For Chile, standard lag-length selection criteria over the entire sample period cannot reject this one-lag specification. This suggests that there is no serial autocorrelation in the residuals and thus no need to consider a higher-order dynamic (results not reported). For the other countries, however, we imposethis lag-structure a priori, without testing its adequacy, to ensure full comparability with the Chilean specification.

Comparing time series models across countries al ways implies a trade-off between the need to i mplement the comparison as neatly as possible and the need to fit models to individual countries as well as possible. If we used different lags for different countries, we would risk losing full comparability. Running the exercise with a common specification across countries, however, carries the risk of comparing Chile with other countries on the basis of a model that is possibly misspecified for other countries. In principle, one could try to determine the optimal lag length for each interest rate series and country considered, but that would involve a core set of about 60 regressions in our analysis. Wethus prefer a common parsimonious specification across all countries and interest rate series because it would be difficult, if not impossible, to uncover the "true" lag length for all cases considered. M oreover, as the sample period is not very long, we would lose efficiency by considering specifications with longer lag structures.

Following Hendry (1995), we then reparameterize and reestimate the ADL in equation (1) as the following error-correction model (ECM):

$\Delta$ RtailR $_{t}=\alpha_{2} \Delta M M R_{t}+\beta_{3}\left(\right.$ Rtail $\left._{t-1}-\beta_{\mathrm{o}}-\beta_{1} \mathrm{t}-\beta_{2} M M R_{\mathrm{t}-1}\right)$,

where

$\beta_{\mathrm{o}}=\frac{\alpha_{\mathrm{o}}}{\left(1-\alpha_{3}\right)}, \beta_{1}=\frac{\alpha_{1}}{\left(1-\alpha_{3}\right)}, \beta_{2}=\frac{\alpha_{2}+\alpha_{4}}{\left(1-\alpha_{3}\right)}$, and $\beta_{3}=\left(\alpha_{3}-1\right)$. 
The parameters of equation (2) are linked to the parameters of equation (1) by equation (3). Hence, estimating the former equation allows all the parameters of the latter to be recovered (and vice versa) without altering the estimated residuals. From a statistical point of view, however, the two representations are not equivalent: if the series are stationary, or nonstationary but cointegrated, then the parameters of equation (2) may be estimated more efficiently because the error-correction term and individual series represented in first differences are less likely to be collinear. If the series are integrated but do not cointegrate, then neither representation is statistically satisfactory. ${ }^{8}$

In equation ( 2 ), the term $\Delta$ Rtail $R_{t}=\alpha_{2} \Delta M M R_{t}+\beta_{3}\left(R\right.$ tail $R_{t-1}-\beta_{0}-$ $\left.\beta_{1} t-\beta_{2} M M R_{t-1}\right)$, which represents the lagged deviation of the retail interest rate from its steady state value, can be interpreted as the solution of a representative bank's optimization problem, as, for instance, in themodel devel oped by Bondt (2002) and those reviewed by F reixas and Rochet (1998, chap. 3). Nonethel ess, since our empirical analysis is not tied to any particular structural model, we use equation (2) simply to characterize the dynamic, reduced-form relation between retail and money market interest rates.

Our empirical results focus particularly on the degree of passthrough in the short term $\left(\alpha_{2}\right.$, or the size of the pass-through on impact and thus within a month), the degree of pass-through in the long run $\left(\beta_{2}\right.$, or the size of the pass-through in the long run or in steady state), and the speed of adjustment to the long-run value $\left(\beta_{3}\right)$. The latter variable, together with $\alpha_{2}$, determines the average number of months needed to reach the long run of the pass-through: $\left(1-\alpha_{2}\right) / \beta_{3}$. This is sometimes called the mean lag.

\section{Results}

In this section, we report and discuss the estimation results. We begin by presenting a set of benchmark results for all the countries

8. As noted, all Chilean interest series are stationary, while most non-Chilean series appear to have a unit root. Therefore, in the case of Chile, it would be pointless to investigate the presence of cointegration between the money market and retail interest rates. For the other countries, we find that a standard augmented Dickey-Fuller (ADF) test on the estimated long-run relation (RTAILR $\beta_{0} \beta_{1} t-\beta_{2} M M R$ ) rejects the null hypothesis of a unit root in most cases. This suggests the presence of cointegration in the vast majority of the cases analyzed. 
considered. We then check whether these results are robust across different states of the interest rate or monetary policy cycle and stable over time. We perform these robustness checks only for Chile. These tests help us interpret the small cross-country differences in passthrough that we detect in the benchmark results.

\subsection{Is Chile's Interest Rate Pass-through Atypical?}

The benchmark set of estimation results reported in table 5 suggests that, overall, Chile's interest rate pass-through is not atypical. In Chile, the pass-through appears incomplete even in the long-run, but this is also true for most European countries, for New Zealand, and for Australian deposit rates. ${ }^{9}$ Pass-through appears compl ete only in the case of the Australian lending rate analyzed, Canada, and the United States. For Chile, however, the size of the short-term passthrough is larger than in Europe, Australia, or New Zealand. As a result, the Chilean mean lag is markedly smaller than in Europe, and it is comparable to that in Australia, Canada, N ew Zealand, and the United States. In fact, the mean Iag for Chile is at most four months, compared with a mean lag of at most two months for $\mathrm{New}$ Zealand and the United States. ${ }^{10}$

As one might expect, the shorter the maturity of the bank lending or deposit instrument, the larger and faster the pass-through. For given maturities, there appears to be only a small difference between deposit and loan rates. Moreover, in the case of Chile, we find little difference between the pass-through to UF and nominal interest rates.

Chile and Europe display slightly less than full pass-through, but the reasons appear different. In Chile, incomplete but relatively fast pass-through appears more likely to be due to external macroeconomic factors than to market power in the banking system, if one is willing to assume that lower persistence in interest rates is primarily due to external shocks. In the case of Europe, the existing literature points

9. The reported estimate for Europe is an average of the individual country estimates. The literature on dynamic panel data models (for example, Pesaran and Smith, 1995) shows that such an average may yield a consistent estimate of the typical relation in the cross section. Its efficiency may be questioned in this case given the small number of country estimates available, but such an averaging is statistically legitimate and economically sensible.

10. The mean lag for short-maturity interest rates in Chile is less than a month. It follows that one should not expect a statistically significant difference between the short- and long-run pass-through coefficient estimates. 


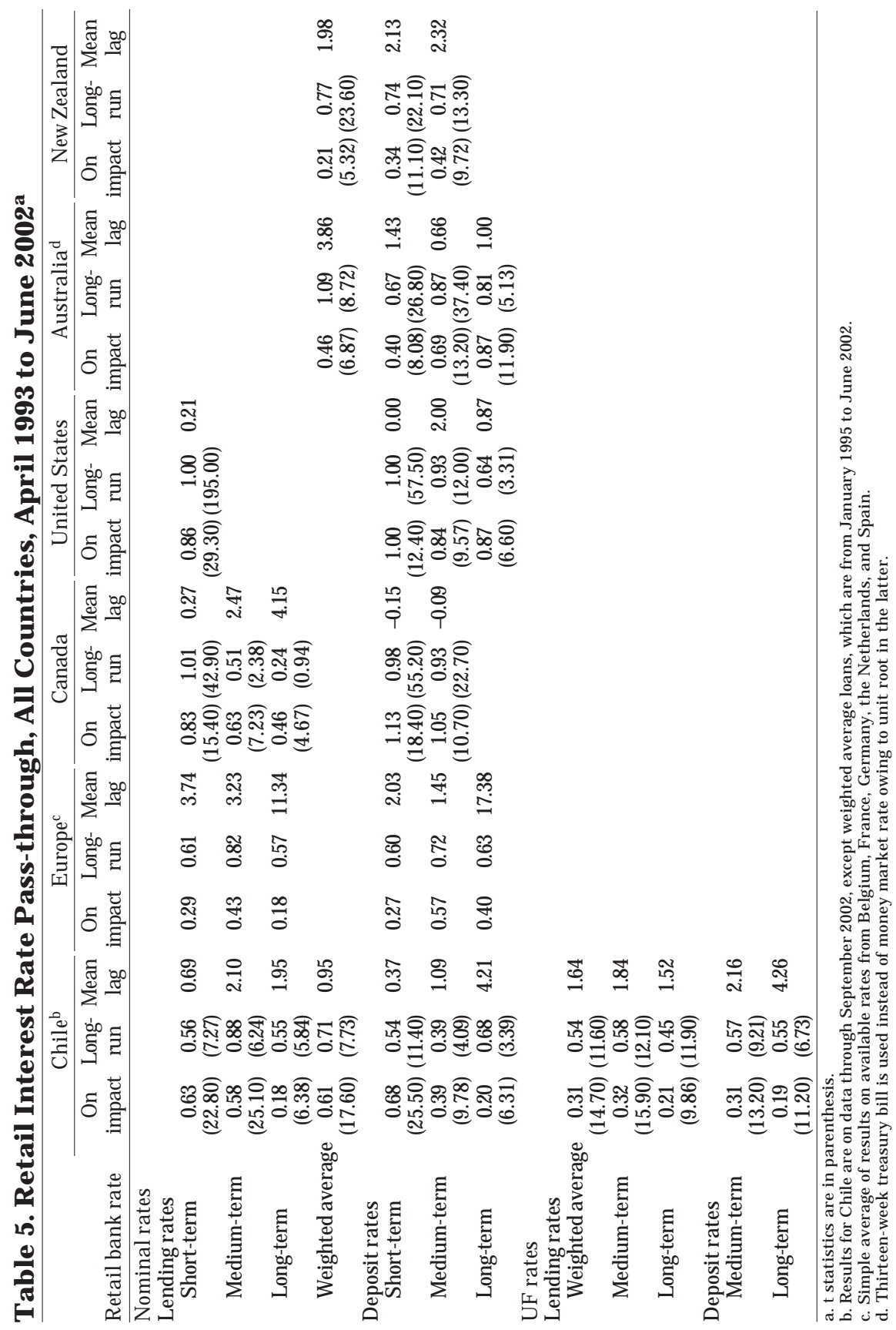


to some role for market power in the banking sector. ${ }^{11}$ As evident from equation (3), for a given size of the short-term pass-through $\left(\alpha_{2}+\alpha_{4}\right)$, the size of the long-run pass-through $\left(\beta_{2}\right)$ is an increasing function of the persistence parameter, $\alpha_{3}$, which in turn is a decreasing function of interest rate vol atility. Chile's long-run pass-through and the correlation between money market and retail interest rates is comparable to Europe's (tables 4 and 5). At the same time, the short-term pass-through is higher in Chile than in Europe, while interest rate persistence (and volatility) of both money market and retail interest rates is lower (higher) in Chile than in Europe (table 3), thus reconciling the differences and similarities noted in section 1 , as well as the econometric results reported here.

How to interpret these results? Chile has a financial structure in which domestic capital markets have played an increasingly important role over the last decade. In addition, the Chilean banking system is exposed to competition not only from domestic capital markets but also from foreign banks. The Chilean banks might thus havelimited market power even if the banking system exhibits some degree of concentration-at least with regard to the largest borrowers that have access to both domestic and foreign capital markets.

This conjecture is not incompatible with some role for banks' behavior in the explanation of incomplete pass-through, but it de-emphasizes the role of market power to highlight therole of the relatively high degree of openness to trade in goods and assets of the Chilean economy. Domestic and foreign banks operate in a rather volatile external environment by international standards. As noted in section 1, bank intermediation may be riskier in Chile than in other economies (because of the more volatile external environment or other reasons). I ndeed, banks' pricing decisions might be slowed down by the high degree of uncertainty. On the other hand, banks might also react promptly to monetary policy impulses, but external shocks force frequent and sometimes sharp policy changes in policy rates, resulting in a fast but less than full pass-through, on average. Either way, by affecting banks' behavior or interest rate persistence, volatility induced by external shocks might result in slower and more incomplete pass-through than otherwise.

11. This interpretation is consistent with the observation by Cottarelli and Kourelis (1994) that reducing the fluctuations in money market rates could help enhance the size of pass-through, although they tie a reduction in the money market rate volatility to structural regulatory changes, rather than external shocks. 
If incomplete pass-through were due mainly to market power in the banking system, one would expect this to result in an asymmetric pass-through in periods of increasing and decreasing interest rates. On the other hand, if external shocks were the main factor affecting pass-through incompleteness, one would expect to find evidence of a more complete pass-through beforetheAsian, Russian, Brazilian, and Argentine crises that buffeted Chile after J une 1997. While we cannot discriminate between these two competing hypothesis based only on aggregate macroeconomic data, in the next two subsections, we assess the robustness of the benchmark estimation results presented here and their interpretation by investigating whether the Chilean pass-through is characterized by asymmetries across states of the interest rate cycle or by instability over time.

\subsection{Is Chile's Interest Rate Pass-through Asymmetric?}

To investigate this hypothesis, we follow Sarno and Thornton (2003) in creating a dummy variable that is equal to one if the retail rate is above or equal to its long-run equilibrium level - given by the estimated error-correction term (RTAILR $-\beta_{0}-\beta_{1} \mathrm{t}-\beta_{2} \mathrm{MMR}$ )-and zero otherwise. We then reestimate the model in equation (2) by interacting the coefficients $\alpha_{2}$ and $\beta_{3}$ with this dummy. ${ }^{12}$ We thus obtain estimates for the size of the short-term pass-through and its speed of adjustment in the two states of the interest rate cycle, which we call interest rate tightening and easing, respectively.

Surprisingly, we find little evidence of asymmetry in the passthrough for Chile when measured in this manner (table 6). In most cases, either the estimates of the parameter of interest in one state are not statistically different from those in the other state or the significant differences have the wrong sign.

The approach used by Sarno and Thornton (2003) to investigate these asymmetries does not address whether the deviations from the long-run equilibrium relationship are caused by changes in the stance of monetary policy or other temporary shocks. We experimented with a different dummy to explore the possibility that asymmetric behavior is more pronounced when the deviations from the long-run equilibrium are associated with policy shocks. This variable tracks

12. $\beta_{2}$ is kept constant in this exercise. Sarno and Thornton (2003) also keep $\alpha_{2}$ constant. 


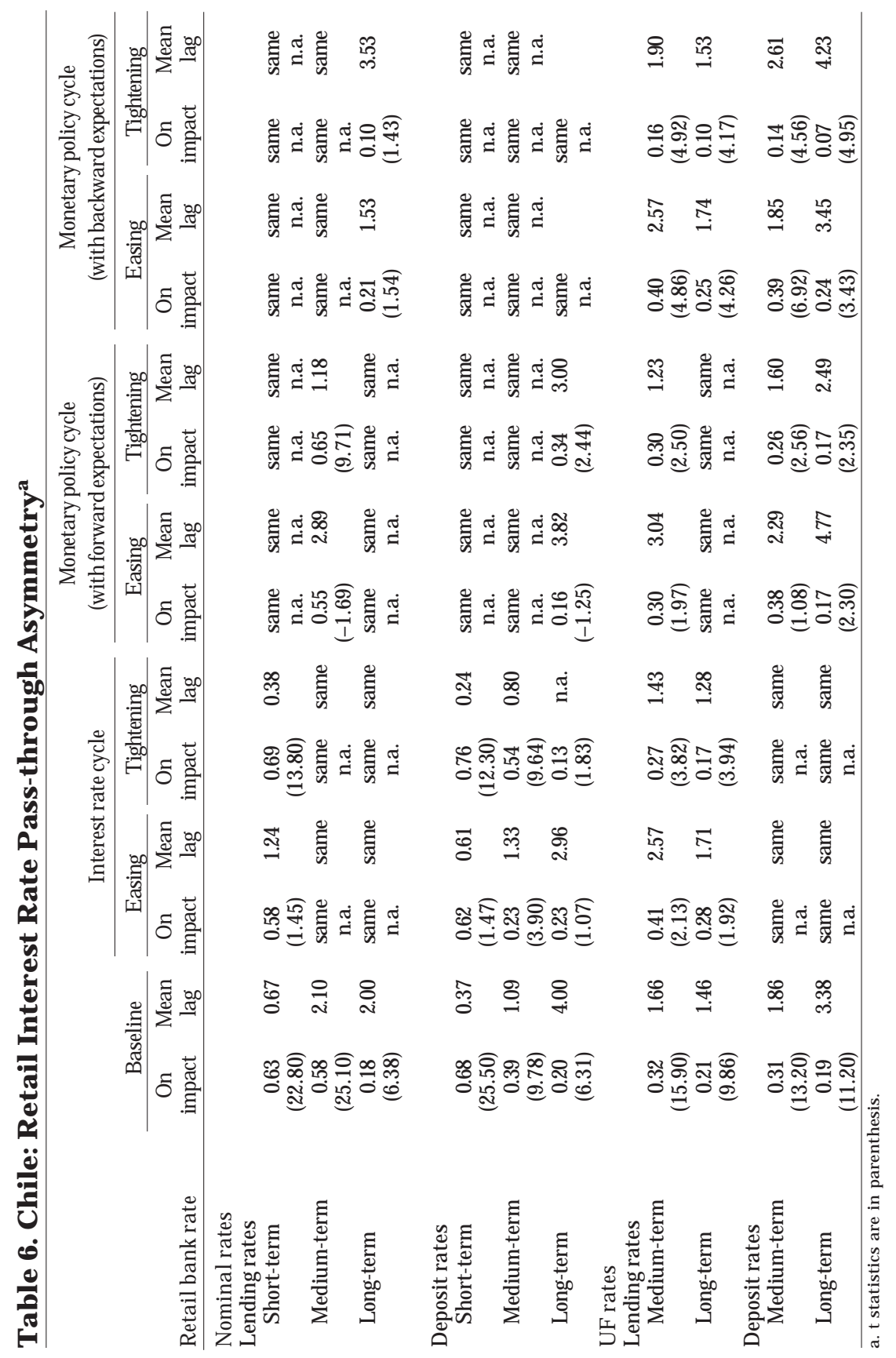


tightening and easing in the monetary policy stance more closely than the previous approach, and it is based on the publicly announced target for the money market interest rate (figure 8 ). ${ }^{13}$ Again, as shown in table 6, we find little evidence of asymmetry in the pass-through for Chile irrespective of the source of the deviation from the long run equilibrium.

\section{Figure 8. Chile: Timing of the Monetary Policy Cycle, 1993 to 2002}
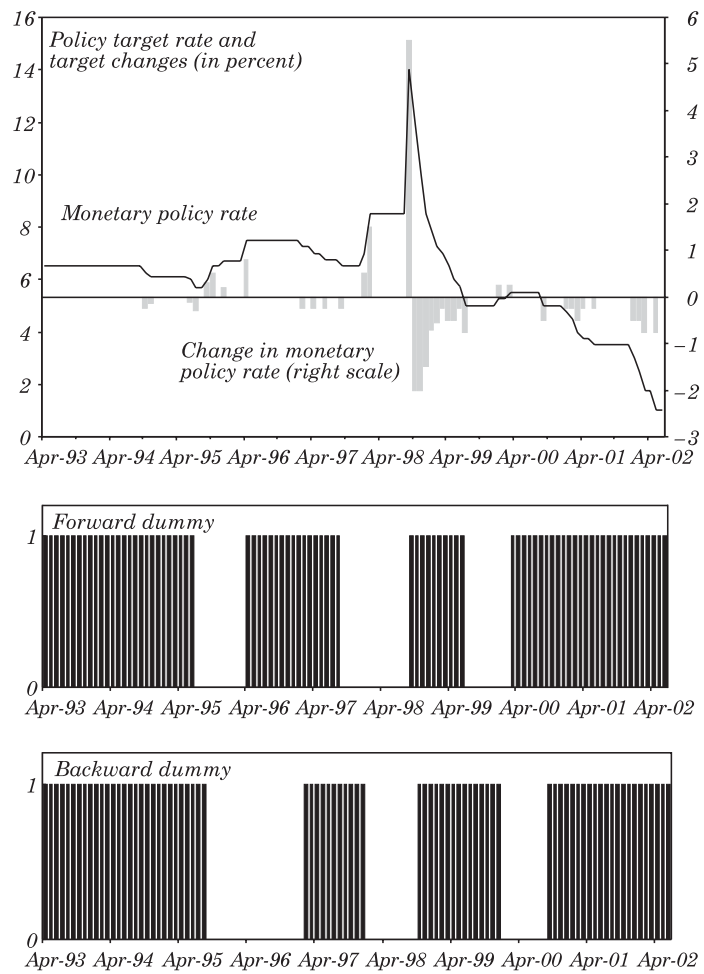

Sources: Central Bank of Chile and IMF staff estimates.

13. This variable, called forward (backward) dummy in figure 8 , is equal to one if the next (previous) policy change is an interest rate target decrease. This approach is similar to the one used by Mojon (2000), who identifies interest rate cycles directly by inspecting plots of retail interest rates. We also considered the possibility of disentangling the impact of the banking structure on the pass-through by comparing the response of retail banking rates with that of market interest rates of similar maturities. However, data availability prevented us from carrying out this type of analysis. 
Hannan and Berger (1991) and N eumark and Sharpe (1992) find evidence of asymmetric pass-through for deposit rates in the United States and concluded that the most likely explanation is banking market power. It might be possible to conclude, on the basis of their argument, that the lack of asymmetric pass-through for the Chilean banking system means absence of market power. This evidence cannot be conclusive, however. In fact, using bank level data, Bernstein and Fuentes (in this volume) find evidence that they interpret as suggesting that market power may be present in some segments of the Chilean banking system.

\subsection{Is Chile's Interest Rate Pass-through Stable over Time?}

To determine whether Chile's interest rate pass-through has changed in recent years as a result of international crises, changes in the exchange rate regime, and, most recently, the nominalization of monetary policy, we follow Morandé and Tapia (2002) by reestimating the model over three progressively longer samples: a subsample that excludes the Argentine crisis and the nominalization of monetary policy (so that it ends in J une 2001), a subsample that excludes the whole free-floating period (this sample ends in J une 1999), and a subsample that excludes the entire Asian-Russian financial crisis period (and subsequent periods, ending in J une 1997). Table 7 reports the estimates of our parameters of interest for Chile.

Theevidence on parameter stability suggests that the pass-through might have slowed down in the post-1997 period. There is less evidence, however, that things changed further after 1997. The estimates for UF-denominated interest rates based on the samplethrough $J$ une 1997, in particular, appear to differ somewhat from those obtained on longer samples. These estimates display larger pass-through in the long run than those based on longer sample periods. ${ }^{14}$

Summary statistics on the raw data are consistent with this econometric evidence: table 2 indicates that the standard deviation of UFdenominated interest rates through J une 1997 is only about a third

14. Those estimates of the long-run pass-through based on the shortest sample period that appear equal to zero result from an estimated $\alpha_{4}$ equal in size to $\alpha_{2}$ but of the opposite sign, thus annihilating the term $\left(\alpha_{2}+\alpha_{4}\right)$ and hence also the long-term pass-through. These are cases in which a different, possibly even shorter lag length would likely be appropriate (say, including only contemporaneous variables). 


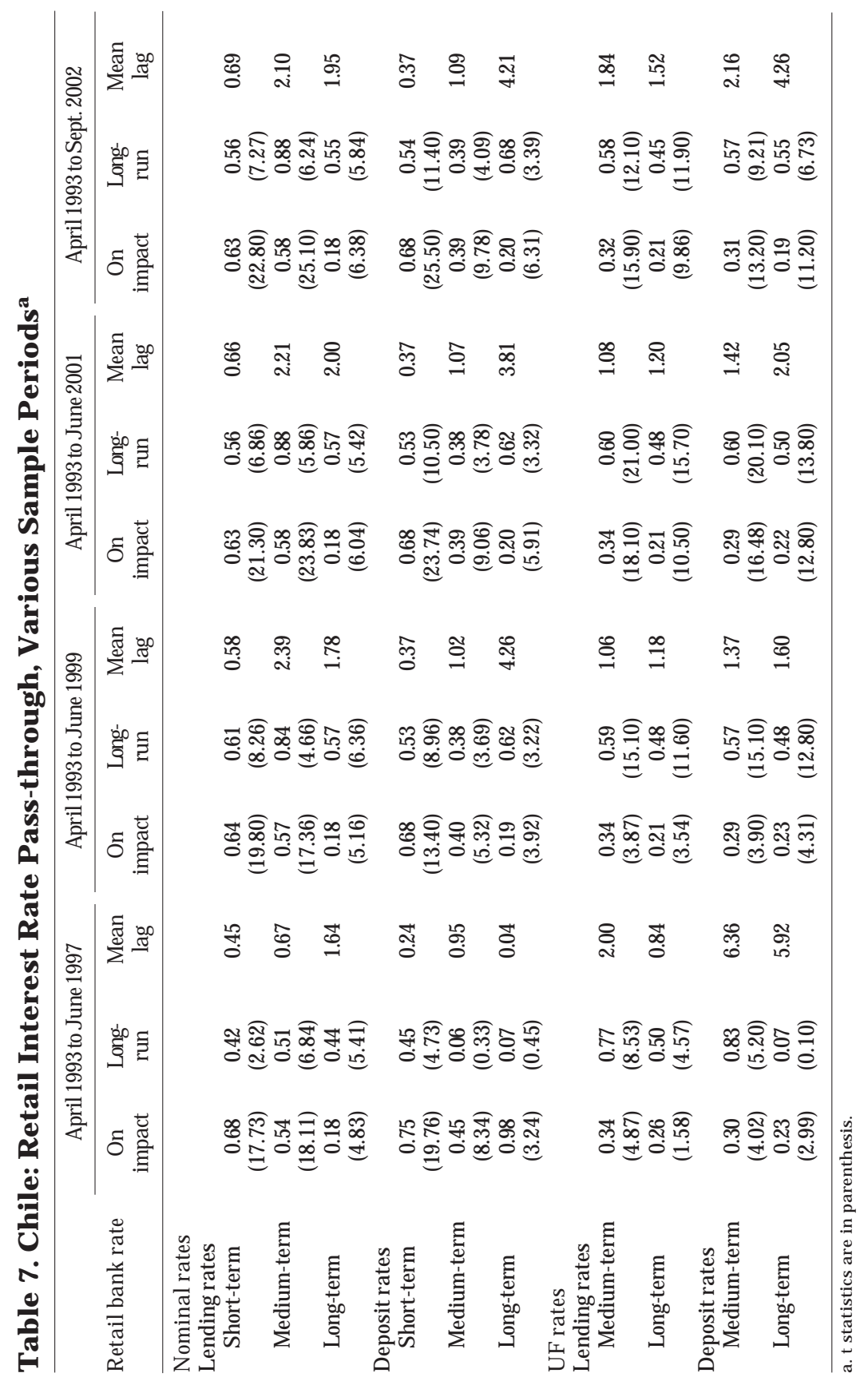


of that computed on longer sample periods, while table 3 shows that the persistence of the money market rate is about 25 percent higher. This suggests a break after mid-1997. The fact that the break occurred at the time of the Asian and Russian crises supports the view that pass-through incompleteness, in the case of Chile, is morelikely due to external shocks than to market power in the banking system.

The changes in exchange rate and monetary policy regimes that took place in September 1999 and August 2001, respectively, do not appear to have had much impact on the interest rate pass-through over and above the impact of the external environment. The estimates based on the two sub-samples through J une 2001 and J une 1999 are essentially identical to that based on the entire sample period (through September 2002). In particular, though it might beearly to assess the effects of nominalization of monetary policy, these re sults suggest that nominalization has had no significant impact on the interest rate pass-through.

A standard stability test based on recursive ordinary least squares (OLS) estimates from April 1997 onward confirms the broad thrust of the these conclusions. As shown in figure 9, the estimated model displays clear signs of parameter instability around the time of the Asian and Russian and only much weaker evidence of instability after mid-1999 and mid-2001.

\section{Figure 9. Chile: One-step Chow Test, 1993 to $2002^{a}$}
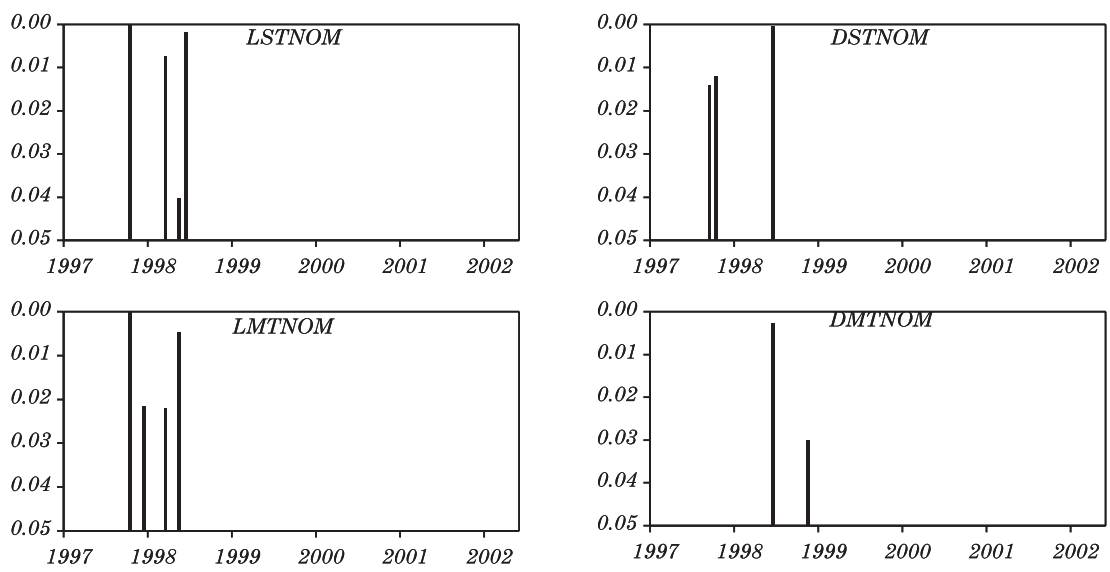


\section{Figure 9. (continued)}
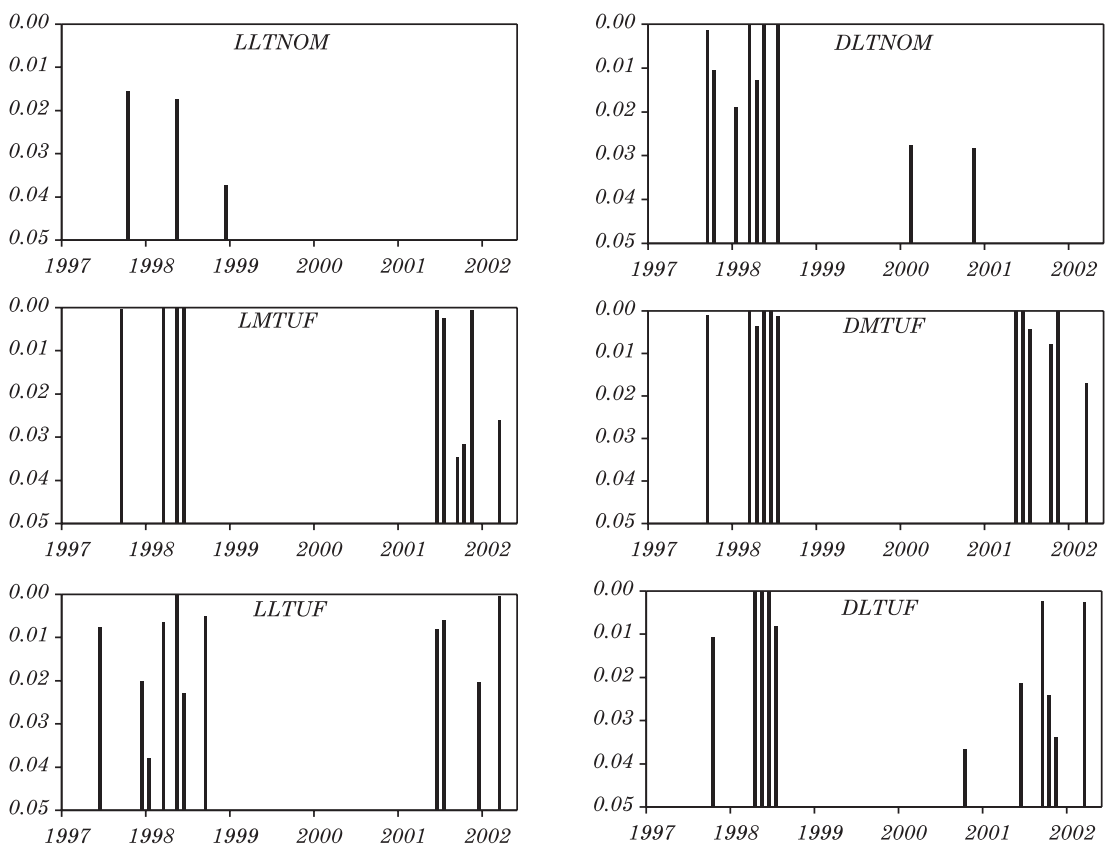

Source: IMF staff estimates.

a. $\mathrm{P}$ values less than 0.05 (that is, greater than 95 percent significance). The null hypothesis is parameter stability.

\section{Conclusions}

In this paper, we have conducted an empirical analysis of the pass-through of changes in money market interest rates to retail banking deposit and lending interest rates. We have compared Chile with Australia, Canada, New Zealand, the U nited States, and five European countries. Based on broadly comparable aggregate monthly data from 1993 to 2002 and an identical standard error-correction econometric specification, we found that, overall, Chile's pass-through is not atypical. Although our results indicate that Chile's pass-through is incomplete in the long run, the same holds for most of the other countries considered. Chilean interest rates are more volatile and less persistent than in many other countries, but the pass-through in the short term is larger than in many of these countries. Chile's passthrough is also faster than in most other countries. 
Slow or incomplete pass-through is usually attributed to market power in the banking system. This paper, however, suggests that external volatility should be considered more carefully as a possible factor giving rise to pass-through incompleteness in a small open economy. Indeed, we have argued that it is plausible that external vol atility could be responsible for a fast but incomplete pass-through in Chile.

We find no significant evidence of asymmetric behavior across states of the interest rate cycle, regardless of the criterion used to identify different states of the cycle. On the other hand, we do find some evidence of parameter instability around the time of the Asian crisis. The pass-through mechanisms appear faster and more complete beforeJ une 1997 (that is, before the Asian and Russian crises), especially for UF-denominated interest rates. However, we showed that neither the switch to a fully flexible exchange rate regime in 1999 nor the adoption of nominal interest rate targeting in August 2001 seems to have affected pass-through markedly.

These results are consistent with the view that the differences between Chileand the other countries we have studied, if any, are due mainly to external shocks, rather than to differences in market power in the banking system or to the recent changes in Chile's exchange rate and monetary policy regimes. It would ther efore be interesting to evaluate this hypothesis more rigorously on microeconomic data based on the predictions of a banking sector model of imperfect competition in an open economy. 


\section{Appendix \\ Interest Rate Descriptions and Abbreviations}

\begin{tabular}{|c|c|c|}
\hline Country and type of rate & Abbreviation & Description \\
\hline \multicolumn{3}{|l|}{ Chile } \\
\hline Monetary policy rate & tpm & $\begin{array}{l}\text { Monetary policy rate of the Central Bank, used } \\
\text { for setting the interbank lending rate. Real } \\
\text { ratethrough J uly 2001; real rateis derived } \\
\text { from nominal thereafter }\end{array}$ \\
\hline \multirow[t]{2}{*}{ Overnight interbank rate } & mmrnom & $\begin{array}{l}\text { Nominal money market rate: overnight interbank } \\
\text { lending rate }\end{array}$ \\
\hline & $\mathrm{mmrrl}$ & $\begin{array}{l}\text { UF money market rate: overnight interbank } \\
\text { lending rate adjusted by previous month's } \\
\text { inflation }\end{array}$ \\
\hline \multirow[t]{5}{*}{ Deposit rates } & dstnom & $\begin{array}{l}\text { Nominal deposit rate on commercial and con- } \\
\text { sumer deposits of } 30 \text { to } 89 \text { days }\end{array}$ \\
\hline & dmtnom & $\begin{array}{l}\text { Nominal deposit rate on commercial and con- } \\
\text { sumer deposits of } 90 \text { to } 365 \text { days }\end{array}$ \\
\hline & dmtuf & $\begin{array}{l}\text { Deposit rate on commercial and consumer de- } \\
\text { posits in UF of } 90 \text { to } 365 \text { days }\end{array}$ \\
\hline & dltnom & $\begin{array}{l}\text { Nominal deposit rate on commercial and con- } \\
\text { sumer deposits of } 1 \text { to } 3 \text { years }\end{array}$ \\
\hline & dltuf & $\begin{array}{l}\text { Deposit rate on commercial and consumer de- } \\
\text { posits in UF of } 1 \text { to } 3 \text { years }\end{array}$ \\
\hline \multirow[t]{7}{*}{ Lending rates } & Istnom & $\begin{array}{l}\text { Nominal lending rate on commercial and con- } \\
\text { sumer loans of } 30 \text { to } 89 \text { days }\end{array}$ \\
\hline & Imtnom & $\begin{array}{l}\text { Nominal lending rate on commercial and con- } \\
\text { sumer loans of } 90 \text { to } 365 \text { days }\end{array}$ \\
\hline & Imtuf & $\begin{array}{l}\text { Lending rate on commercial and consumer loans } \\
\text { in UF of } 90 \text { to } 365 \text { days }\end{array}$ \\
\hline & Iltnom & $\begin{array}{l}\text { Nominal lending rate on commercial and con- } \\
\text { sumer loans of } 1 \text { to } 3 \text { years }\end{array}$ \\
\hline & Iltuf & $\begin{array}{l}\text { Lending rate on commercial and consumer loans } \\
\text { in UF of } 1 \text { to } 3 \text { years }\end{array}$ \\
\hline & Iwtnom & Weighted average interest rate on peso loans \\
\hline & 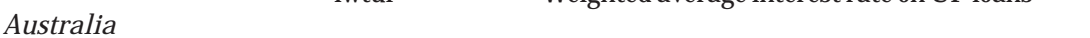 & Weighted averageinterest rate on UF Ioans \\
\hline Overnight interbank rate & atrb & $\begin{array}{l}\text { Thirteen-week treasury bill used because of } \\
\text { irregularities in the money market rate. }\end{array}$ \\
\hline Deposit rates & $\begin{array}{l}\text { adst } \\
\text { admt } \\
\text { adlt }\end{array}$ & $\begin{array}{l}\text { Bank deposits of } 3 \text { months } \\
\text { Bank deposits of } 6 \text { months } \\
\text { Bank deposits of } 1 \text { year }\end{array}$ \\
\hline $\begin{array}{l}\text { Lending rate } \\
\text { Belgium }\end{array}$ & alwt & Weighted average of all loans \\
\hline Overnight interbank rate & bmmr & Overnight interbank rate \\
\hline Deposit rates & $\begin{array}{l}\text { bdst } \\
\text { bdmt }\end{array}$ & $\begin{array}{l}\text { Deposits of less than } 3 \text { months } \\
\text { Deposits of } 3 \text { months to } 1 \text { year }\end{array}$ \\
\hline Lending rates & $\begin{array}{l}\text { blst } \\
\text { blmt } \\
\text { bllt }\end{array}$ & $\begin{array}{l}\text { Commercial loans of } 6 \text { months } \\
\text { Commercial loans of up to } 1 \text { year } \\
\text { Commercial loans of } 1 \text { to } 5 \text { years }\end{array}$ \\
\hline
\end{tabular}




\section{ApPendix (continued)}

\begin{tabular}{|c|c|c|}
\hline Country and type of rate & Abbreviation & Description \\
\hline \multicolumn{3}{|l|}{ Canada } \\
\hline Overnight interbank rate & cammr & Overnight interbank lending rate \\
\hline Deposit rates & $\begin{array}{l}\text { cdst } \\
\text { cdmt }\end{array}$ & $\begin{array}{l}\text { Commercial certificates of deposit of } 30 \text { days } \\
\text { Commercial certificates of deposit of } 90 \text { days }\end{array}$ \\
\hline Lending rates & $\begin{array}{l}\text { clst } \\
\text { clmt } \\
\text { cllt }\end{array}$ & $\begin{array}{l}\text { Prime business short-term lending rate } \\
\text { Conventional mortgagerate, } 1 \text { year } \\
\text { Conventional mortgagerate, } 3 \text { years }\end{array}$ \\
\hline \multicolumn{3}{|l|}{ France } \\
\hline Call money rate & fmmr & Call money rate \\
\hline Deposit rates & $\begin{array}{l}\text { fdst } \\
\text { fdlt }\end{array}$ & $\begin{array}{l}\text { Deposits of up to } 3 \text { months } \\
\text { Deposits of } 1 \text { to } 2 \text { years }\end{array}$ \\
\hline Lending rates & $\begin{array}{l}\text { flmt } \\
\text { fllt }\end{array}$ & $\begin{array}{l}\text { Commercial loans of up to } 1 \text { year } \\
\text { Commercial loans of over } 1 \text { year }\end{array}$ \\
\hline \multicolumn{3}{|r|}{ 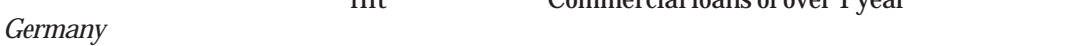 } \\
\hline Overnight interbank rate & gmmr & Overnight interbank rate \\
\hline Deposit rates & $\begin{array}{l}\text { gdst } \\
\text { gdmt } \\
\text { gdlt }\end{array}$ & $\begin{array}{l}\text { Deposits of } 1 \text { to } 3 \text { months } \\
\text { Deposits of } 3 \text { months to } 1 \text { year } \\
\text { Deposits of over } 3 \text { months notice period }\end{array}$ \\
\hline Lending rates & glmt & $\begin{array}{l}\text { Commercial loans of up to } 1 \text { year } \\
\text { Consumer loans of greater than } 1 \text { year }\end{array}$ \\
\hline \multicolumn{3}{|l|}{ Netherlands } \\
\hline Overnight interbank rate & $\mathrm{nmmr}$ & Overnight interbank rate \\
\hline Deposit rates & $\begin{array}{l}\text { ndst } \\
\text { ndlt }\end{array}$ & $\begin{array}{l}\text { Demand deposits } \\
\text { Deposits of } 2 \text { years }\end{array}$ \\
\hline $\begin{array}{l}\text { Lending rate } \\
\text { Spain }\end{array}$ & nlmt & Spain \\
\hline Overnight interbank rate & smmr & Overnight interbank rate \\
\hline Deposit rates & $\begin{array}{l}\text { sdst } \\
\text { sdlt }\end{array}$ & $\begin{array}{l}\text { Deposits of overnight } \\
\text { Deposits of } 1 \text { to } 2 \text { years }\end{array}$ \\
\hline Lending rates & $\begin{array}{l}\text { slmt } \\
\text { sllt }\end{array}$ & $\begin{array}{l}\text { Commercial loans of up to } 1 \text { year } \\
\text { Commercial loans of } 1 \text { to } 3 \text { years }\end{array}$ \\
\hline \multicolumn{3}{|l|}{ New Zealand } \\
\hline Overnight interbank rate & $\mathrm{zmmr}$ & Overnight interbank rate \\
\hline Deposit rates & $\begin{array}{l}\text { zdst } \\
\text { zdmt }\end{array}$ & $\begin{array}{l}\text { Call deposit rate } \\
\text { Bank deposits of } 6 \text { months }\end{array}$ \\
\hline $\begin{array}{l}\text { Lending rate } \\
\text { United States }\end{array}$ & zlwt & Weighted average of all loans \\
\hline Federal funds rate & fed & Overnight interbank lending rate \\
\hline Deposit rates & udst & $\begin{array}{l}\text { Average of dealer offering rates on nationally } \\
\text { traded certificates of 1-month deposits }\end{array}$ \\
\hline & udmt & $\begin{array}{l}\text { Average of dealer offering rates on nationally } \\
\text { traded certificates of 3-month deposits }\end{array}$ \\
\hline & udlt & $\begin{array}{l}\text { Deposits of } 9 \text { to } 12 \text { months at the F ederal Home } \\
\text { Loan Bank of New Y ork }\end{array}$ \\
\hline Lending rate & ulst & $\begin{array}{l}\text { Primelending rate: overnight loans to } \\
\text { businesses }\end{array}$ \\
\hline
\end{tabular}




\section{References}

Bernanke, B. and M. Gertler. 1995. "I nside the Black Box: The Credit Channel of Monetary Policy Transmission."J ournal of E conomic Perspectives 9(4): 27-48.

Bernanke, B. and S. Gilchrist. 1999. "The Financial Accelerator in a Quantitative Business Cycle Framework." In Handbook of Macroeconomi cs, edited by M. Woodford and J .B. Taylor, chapter 21. Amsterdam: Elsevier Science.

Berstein, S. and J .R. Fuentes. 2003. "Is There Lending Rate Stickiness in the Chilean Banking I ndustry?" In Banking Market Structure and Monetary Policy, edited by L.A. Ahumada and J.R. Fuentes. Santiago: Central Bank of Chile.

Bondt, G. 2002. "Retail Bank Interest Rate Pass-through: New Evidence at the Euro Area Level." Working paper 132. Frankfurt: European Central Bank.

Borio, C. and W. Fritz. 1995. “The Response of Short-term Bank Lending Rates to Policy Rates: A Cross-country Perspective." In Financial Structureand the Monetary Transmission Mechanism. Basel: Bank for I nternational Settlements.

Caballero, R. 2000. "Macroeconomic Volatility in Latin America: A View and Three Case Studies," Working paper 7782. Cambridge, Mass.: National Bureau of Economic Research.

Cottarelli, C. and A. Kourelis. 1994. "Financial Structure, Bank Lending Rates, and the Transmission Mechanism of Monetary Policy." IMF Staff Papers 41(4): 587-623.

Edwards, S. 1998. "I nterest RateVolatility, Capital Controls and Contagion." 6756. Cambridge, Mass.: National Bureau of Economic Research.

Freixas, X. and J .-C. Rochet. 1998. Microeconomics of Banking. MIT Press.

Hannan, T. and A. Berger. 1991. "The Rigidity of Prices: Evidence from the Banking Industry." American Economic Review 81(4): 938-45.

Hendry, D.F. 1995. Dynamic E conometrics. Oxford University Press. MorandéF . and M. Tapia. 2002. "Exchange RatePolicy in Chile: From the Band to Floating and Beyond." Working paper 152. Santiago: Central Bank of Chile.

Mojon, B. 2000. "Financial Structure and the Interest Rate Channel of the ECB Monetary Policy." Working paper 40. Frankfurt: European Central Bank. 
Neumark, D. and S. Sharpe. 1992. "Market Structureand the Nature of Price Rigidity: Evidence from the Market for Consumer Deposits." QuarterlyJ ournal of Economics 107(2): 657-80.

Pesaran, M.H. and R. Smith. 1995. "Estimating Long-run Relationships from Dynamic Heterogeneous Panels." J ournal of Econometrics 68(1): 79-113.

Sarno, L. and D. Thornton. 2003. “The Dynamic Relationship between the Federal Funds Rateand theTreasury Bill Rate: An Empirical Investigation."J ournal of Banking and Finance27(6): 1079-110. 